\title{
Pudridero 2
}

\section{Johnny Ryan}

\section{Fulgencio Pimentel / Entrecomics Comics, 2013}

\section{VENGA, MAS MIERDA QUE MATAR}

De pequeño mis padres pensaban que podía sufrir algún tipo de autismo, no sin razón. De hecho, todavía les doy alguna que otra excusa para alimentar la leyenda. Siendo un niño feliz, extraño a los problemas de adulto aún por venir, me encerraba en casa feliz con mis clicks de Famobil en lugar de darle patadas al cuero con los chavales del barrio. Vida social nula $v s$. rica vida interior. Organizaba mis gigantescos campamentos de juguete con toda la parafernalia multicolor ocupando toda mi habitación. Montaba mis películas con extras inanimados que aceptaban sus roles sin


protesta alguna. Atrezzo y decorados sin cortapisas, el sueño de cualquier cineasta en proceso de fermentación. Batallas monumentales en las que también participaban Airgam Boys y Coman Boys, o bichos de goma de a saber qué procedencia, como si fuera la mitología de El Señor de los Anillos, sin haber leído todavía a Tolkien, con varias tribus partiéndose la cara por un puñado de monedas de plástico. El barco pirata era lo más y la estación espacial de Comansi ni te cuento. Aquel entretenimiento mayúsculo, alimento para el alma, dejó un poso de infancia fantástica en mi currículum vital que a día de hoy alimenta el Peter Pan que muchos lectores de tebeos, por no decir todos, llevamos dentro. Al leer la serie Pudridero de Johnny Ryan, un sujeto al que no tenía en muy alta estima — sus chistecillos pringosos en la revista Vice me caen

CuCo, Cuadernos de cómic número 1. Septiembre de 2013 
antipáticos, sin saber bien por qué-, siento que revivo en cierta manera aquellas historias de peleas entre muñecos tuneados con toda clase de gadgets, homologados o no. Una figurita en una mano y otra en la otra, izquierda, derecha, adelante y atrás, un, dos, tres... ¡a partirse la cara! ¡Pum!

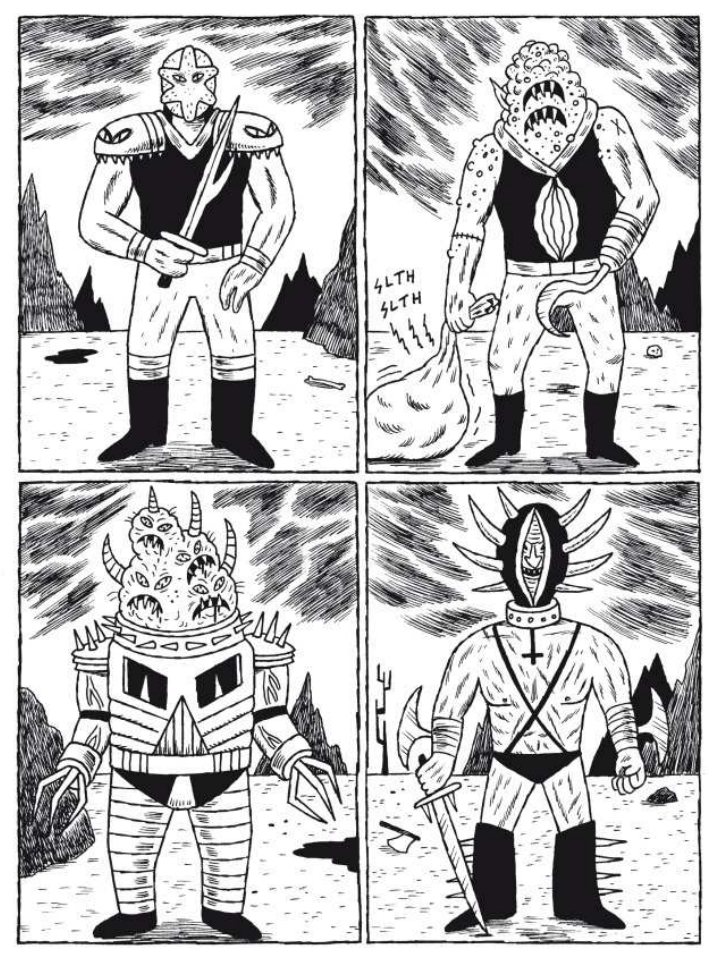

Pudridero 2 (p. 20).

Recuerdo emplear plastilina y otros elementos en la onda para ampliar la gama de armas e inventar indumentarias para los juguetes humanizados que convenientemente deshumanizaba. Todo objeto a mano podía convertirse en un vehículo, una lanza, una armadura o una máquina del tiempo en pos de la diversión. Pudridero refleja esta idea y la lleva al paroxismo, más allá del bien y del mal, impregnando cada página de dulcigore, como diría Pablo Llorens, el rey de la plastianimation, en alguno de cuyos cortometrajes —Gastropotens, El enigma del chico croqueta o Molecular zombi sin ir 
más lejos- sus personajes sufren mutaciones fotograma a fotograma como los grotescos personajes creados por Ryan en un ataque de regresión infantil. Gore en stop motion, viñeta a viñeta en el caso del cómic que nos ocupa, cuyas explícitas líneas, apología de la purulencia, apuestan por el tremendismo propio de los fanzines especializados de los años noventa —repasen las historietas políticamente incorrectas de Ladrón \& Co., a las que no se les hizo mucho caso en su día a la hora de teorizar en el medio y aquí estamos alabando años más tarde algo parecido-. Defendamos con el trabajo de Ryan en la mano la libertad en el trazo, la imaginación sin barreras, la demencia como arte, con el fin de no aprobar únicamente aquellas propuestas intensas que nos hacen sentir adultos. La historieta también es cosa de niños grandes.



Pudridero 2 (p. 58). 
Pueblan las páginas de Pudridero 2 una buena colección de seres esperpénticos que alteran su aspecto, customizado, sorpresivamente, sumidos en la escatología sin freno. Dan para un impagable álbum de cromos. Intercambian mamporros y hachazos con criaturas monstruosas, repugnantes hasta decir basta, fruto de un delicioso surrealismo hemoglobínico que campa a sus anchas a golpe de tinta. Mutilaciones surrealistas, onirismo enfermizo, anatomía desatada sobre papel, grafismo burbujeante de caligrafía nerviosa e infantil. Dibujos que parecen obra de un niño, o de un psicópata, adicto al wrestling, a la pelea de gallos entre sus mascotas preferidas. Garabatos que fluyen retratando las luchas encarnizadas entre muñecos molones, esa es la historia. La explosión de fluidos, el despedazamiento, como giro argumental: la visión macabra de un viaje por planetas inhóspitos dejando un reguero de sangre espacial. Ideas magistrales, como el pegamento anatómico, hace ganar puntos a este puro juego con el dibujo y la narratividad secuencial que deleita especialmente al lector desprejuiciado, contagiado por la energía de un autor que monta una fiesta inusual en cuya segunda entrega se deja llevar por destellos de metafísica de andar por casa y una suerte de acusada locura sideral.

La edición de Fulgencio Pimentel, en colaboración con Entrecomics Comics, es impecable, aunque su hábitat natural, como se ha podido entender, es el fanzine, formato original de esta maravillosa salida de tono cósmica de Ryan, convertida por estos pagos en una colección de tomos de lo más arty. Recomendable, por cierto, devorar el segundo volumen de Pudridero con una banda sonora de fondo donde no pueden faltar Vangelis y algo de death metal. Ahí queda eso. ¡Venga, más mierda que matar!

\section{BORJA CRESPO}

Borja Crespo escribe asiduamente en diversos medios sobre cómic, cine y tendencias, y ha firmado varios libros especializados. Cuenta con una página semanal sobre tebeos en EL CORREO. Ha dirigido festivales de cine y actualmente se dedica a su productora, Arsénico P.C., y a desempeñar tareas como asesor y/o coordinador en diversos eventos culturales, entre ellos el Salón del Cómic de Getxo (desde 2002). En los años 90 capitaneó la editorial independiente Subterfuge Comix. Como dibujante ha

CuCo, Cuadernos de cómic número 1. Septiembre de 2013

$\mathrm{CuCoCrítica}$ 
publicado cuatro referencias (Tales from the Splatter Family, Comic Horror Freak Show, El cielo más alto y Devuélveme mi secreto), además de colaborar en revistas como El Manglar, La Comictiva, Tos, Dos Veces Breve, Rolling Stone, etc. Como guionista firma Cortocuentos (Astiberri, 2009) y Cortocuentos 2 (Astiberri, 2012). Dirigió Mostra Cómic en 2010 y 2011 y estuvo nominado al Premio a la Divulgación en el Salón Internacional del Cómic de Barcelona (2009, 2010, 2011). Ha realizado varios cortometrajes y video-clips, ha producido cortos, spots publicitarios y eventos varios. Ha impartido cursos y clases magistrales de cómic y cine, además de ejercer de jurado en concursos y ejercer como comisario de exposiciones. 